\title{
KANDUNGAN AUKSIN (ASAM 3-INDOL ASETAT) PADA TAHAP PERKEMBANGAN BUAH KACANG TANAH (Arachis hypogaea (L.) Merr.)
}

\author{
Sulistiono*, Issirep Soemardi ** dan Aziz-Purwantoro *** \\ *Mahasiswa Program S-3, Program Studi Biologi Universitas Gadjah Mada, Jl. Tehnika Selatan Yogyakarta \\ ${ }^{* *}$ Fakultas Biologi Universitas Gadjah Mada, Jl. Tehnika Selatan Yogyakarta \\ ${ }^{* \star \star}$ Fakultas Pertanian Universitas Gadjah Mada Yogyakarta, Jl. Sekip Selatan Yogyakarta
}

\begin{abstract}
Auxin has an important role to control both of the growth and tropism of gynophore and the development of fruit and embryo of peanut (Arachis hypogaea (L). Merr.). The experiment was carried out to examine the contents of auxin during peanut development, i.e. at the time of anthesis (day 0), at day 4, 7, 10, 15, 18, 23, and 31 after anthesis, using High Performance Liquid Chromatography (HPLC) with fluorescence detector method.

Between the day of anthesis to the day 31 after anthesis, the auxin contents changed according to fruit development stage. The free auxin contents in the developed fruit (entering the soil) were higher than undeveloped fruit (not entering the soil), while the bound auxin content in the developed fruit were lower than undeveloped fruit. The lowest free auxin contents was found at the time of anthesis, then increased drastically when the gynophore grew fast and in the beginning of embryo development stage (day 7). Between the day 7 to the day 15 after anthesis, the free auxin contents were decreased. In the development fruit, the free auxin contents increased when the fruit begin to grow (day 15-18), then decreased until the seed reached its full size (day 31). In the undeveloped fruit, the free auxin contents decreased at day 7 to day 31. The bound auxin contents in the developed fruit decreased until the day 18, and increased gradually until day 31. In the undeveloped fruit, the bound auxin contents decreased at day 15 and afterward.
\end{abstract}

Key words: auxin, HPLC, fluorescence, Arachis hypogaea, anthesis

\section{PENGANTAR}

Organ reproduksi pada kacang tanah (Arachis hypogaea (L.) Merr.) dan jenis lainnya dari marga Arachis memperlihatkan perkembangan yang agak berbeda apabila dibandingkan dengan marga-marga yang lain dari suku Fabaceae, karena perkembangan buah kacang tanah hanya terjadi di dalam tanah.

Pada kacang tanah, setelah terjadi fertilisasi terbentuk organ khusus yang dinamakan ginofor. Ginofor tersebut selanjutnya tumbuh memanjang dan membawa buah yang berisi biji dan embrio masuk ke dalam tanah (Jakobs, 1951; Patte \& Mohapatra, 1987; Moctezuma \& Feldman, 1998). Apabila ginofor tidak masuk ke dalam tanah, buah, biji, dan embrio tidak mengalami perkembangan (Jakobs, 1951; Patte \& Mohapatra, 1987; Maesen \& Somaatmaja, 1993; Moctezuma \& Feldman, 1998).

Pertumbuhan ginofor dan perkembangan buah kacang tanah dikontrol oleh beberapa zat pengatur tumbuh, seperti giberelin (Amir, 1969; Cutter, 1971), auksin (IAA) (Smith, 1956; Ziv \& Zamski, 1975; Moctezuma \& Feldman, 1998; Moctezuma, 1999), sitokinin (Sushu \& Cutter, 1990 dalam Moctezuma, 1999) serta etilen dan asam absisat (Shlamovitz, 1995 dalam Moctezuma, 1999).

Auksin merupakan salah satu zat pengatur tumbuh yang sangat berperan dalam berbagai proses perkembangan tumbuhan, seperti pemanjangan dan pembelahan sel (Masuda, 1969 dalam Moore, 1989), dominansi apikal (Thimann \& Skoog, 1934 dalam Hopkins, 1995), diferensiasi sel (Wetmore \& Sorokin, 1955 dalam Hall, 1984; Guilfoyle et al., 1998), perkembangan akar (Weier et al., 1982 dalam Hopkins, 1995; Reed et al., 1998), tropisme (Carry \& Thimann, 1961 dalam Ludford, 1990) serta perkembangan buah dan embrio (McGlasson, 1978 dalam Ludford, 1990).

Pada buah kacang tanah, auksin dihasilkan oleh biji dan kulit buah. Auksin tersebut selain digunakan untuk perkembangan buah juga ditranspor secara basipetal melewati ginofor (Smith, 1956; Moctezuma \& Feldman 1998). Peran auksin dalam perkembangan buah kacang tanah antara lain mengontrol pemanjangan dan tropisme ginofor (Smith, 1956; Mnzava \& Flocker, 1978; Moctezume \& Feldman, 1998), perkembangan embrio dan pertumbuhan endosperm (Smith, 1956) serta mengontrol perkembangan buah (Ziv \& Zamski, 1975; Moctezuma, 1999).

Meskipun auksin berperan penting dalam pertumbuhan ginofor dan perkembangan buah kacang tanah, tetapi belum ada informasi tentang kandungan auksin, baik auksin bebas maupun terikat pada setiap tahap perkembangannya. Moctezuma (1999) hanya meneliti distribusi auksin pada 
buah kacang tanah dan belum diketahui kandungan auksin selama tahap perkembangannya.

Berdasarkan uraian di atas, penelitian ini bertujuan untuk mengetahui kandungan auksin buah kacang tanah selama tahap perkembangannya.

\section{BAHAN DAN CARA KERJA}

\section{Penanaman dan pemeliharaan tanaman}

Tanaman kacang tanah yang digunakan dalam penelitian ini adalah varietas Kelinci. Benih diperoleh dari Balai Penelitian Tanaman Kacang-kacangan dan Umbiumbian, Malang. Benih ditanam dalam pot plastik warna hitam dengan diameter $30 \mathrm{~cm}$. Tiap pot ditanami 3 biji dengan kedalaman $\pm 5 \mathrm{~cm}$, lalu ditimbun dengan tanah. Setelah tumbuh dipilih 2 tanaman yang paling baik. Media tanam yang digunakan terdiri atas campuran tanah, pupuk kandang dan pasir dengan perbandingan $3: 2: 1$. Pemupukan dilakukan setelah tanaman berumur 1 minggu dengan pupuk TSP.

\section{Sampel buah}

Buah yang diukur kandungan auksinnya terdiri atas berbagai umur, baik yang mengalami perkembangan (masuk ke dalam tanah) maupun yang tidak berkembang (tidak masuk tanah) yaitu: saat antesis, 4 hari setelah antesis (hsa) (orientasi ginofor geotrofi negatif), 7 hsa (orientasi ginofor geotrofi positif), 15 hsa (buah mulai membesar), 18 hsa (buah berukuran sedang), 23 hsa (buah berukuran maksimal) dan 31 hsa (biji berukuran penuh) (Gambar 1).

\section{Pengukuran pertumbuhan ginofor dan perkembangan buah kacang tanah}

Pertumbuhan ginofor diukur berdasarkan kecepatan pertambahan panjang setiap hari. Pengukuran dilakukan setiap hari sampai berumur 15 hsa (pada ginofor yang masuk tanah) dan sampai umur 24 hsa (pada buah yang tidak masuk tanah). Sedangkan perkembangan buah diukur berdasarkan panjang dan diameter buah serta panjang dan diameter biji. Pengukuran panjang buah dan biji dilakukan dari ujung distal sampai ujung proksimal, sedangkan pengukuran diameter dilakukan pada bagian yang terbesar.

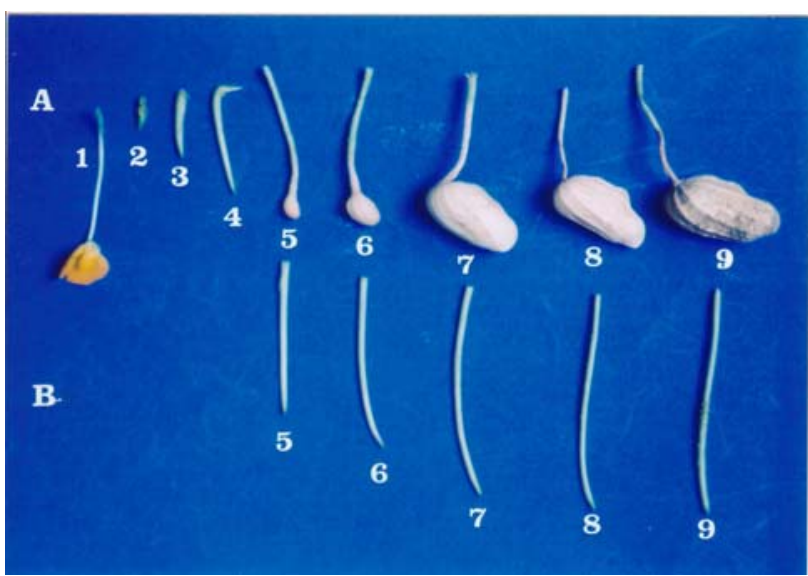

Gambar 1. Tahap-tahap perkembangan buah kacang tanah. (A) Buah masuk ke dalam tanah; (B) Buah tidak masuk ke dalam tanah. (1-9) berturut-turut adalah ginofor dan buah berumur: saat antesis (ginofor belum terbentuk), 4, 7, 10, 15, 18, 23, 31 hsa, dan saat panen

\section{Analisis kandungan auksin}

Kandungan auksin dalam penelitian ini diukur dengan metode Kromatografi Cair Kinerja Tinggi (KCKT) menggunakan detektor fluorescence menurut Crozier et al. (1980) dan Durley et al. (1982).

\section{Ekstraksi dan pemurnian sampel}

Buah segar sebanyak $2 \mathrm{~g}$ (berat basah) dihaluskan dalam $\mathrm{N}_{2}$ cair, kemudian diekstraksi dengan campuran metanol dan air yang mengandung $40 \mathrm{mg} / \mathrm{l}$ Butyl hydroxy toluene (BHT) (80:20; $20 \mathrm{ml})$ pada suhu $5^{\circ} \mathrm{C}$. Setelah dievaporasi, $\mathrm{pH}$ diatur 8 , kemudian disentrifugasi selama 1 jam pada $14.000 \mathrm{rpm}$. Supernatan yang diperoleh diambil dan dibagi menjadi 2 bagian. Satu bagian untuk analisis kandungan auksin total, sedangkan 1 bagian yang lain untuk auksin bebas.

Supernatan untuk analisis kandungan auksin bebas dibiarkan pada suhu kamar, sedangkan untuk auksin total ditambah dengan 0,1 $\mathrm{M} \mathrm{NaOH}$ sebanyak volume supernatan. Besarnya pH masing-masing supernatan (untuk auksin total dan bebas) diatur 3, kemudian diekstraksi dengan dietileter. Setelah dievaporasi kemudian diekstraksi lagi dengan campuran metanol dan dietileter $(1: 1 ; 1 \mathrm{ml})$, serta 6-8 tetes Amonium hidroksida pekat. Selanjutnya ditambah dengan air destilasi yang mengandung BHT dan 
disaring dengan Polyvinyl pyrolidon (PVP) kemudian dengan Fluoropore (ukuran pori 0,5 mm). Hasil penyaringan tersebut selanjutnya siap dikromatografi.

\section{Analisis kandungan auksin dengan KCKT}

Sampel hasil penyaringan dicampur dengan fase gerak (air destilasi : asetonitril : asam asetat $=71: 28: 1 ; 40 \mathrm{ml}$ ), kemudian sebanyak $10 \mathrm{ml}$ diinjeksikan ke dalam kolom ID Beckman Ultrasphere ODS. Kecepatan aliran fase gerak $1 \mathrm{ml} /$ menit, sedangkan panjang gelombang eksitasi dan emisi pada detektor fluorescence masing-masing adalah 254 dan $360 \mathrm{~nm}$.

Kandungan auksin dalam sampel ditentukan dengan cara mengonversikan luas area kurva sampel dengan luas area kurva auksin standar yang telah diketahui konsentrasinya. Dari beberapa luas area kurva standar selanjutnya dibuat hubungan antara luas area dengan kandungan auksin, yaitu dalam bentuk persamaan regresi.

Kandungan auksin terikat ditentukan dengan cara mengurangi kandungan auksin total dengan kandungan auksin bebas.

\section{HASIL}

\section{Pertumbuhan ginofor dan perkembangan buah kacang tanah}

Pertumbuhan ginofor mula-mula ke arah geotrofi negatif, dan setelah berumur 6 hsa berubah ke arah geotrofi positif. Pada ginofor yang masuk ke dalam tanah, ketika buah mulai membesar arah pertumbuhannya berubah horisontal, sedangkan pada ginofor yang tidak masuk ke dalam tanah arah pertumbuhannya tetap geotrofi positif. Pertumbuhan ginofor mula-mula lambat (1-3 hsa), meningkat dengan cepat pada umur 4-7 hsa, lalu relatif konstan pada 7-8 hsa. Pertumbuhan ginofor mengalami penurunan setelah 8 hsa, dan pada ginofor yang masuk tanah terhenti pada umur 15 hsa, sedangkan pada ginofor yang tidak masuk tanah terhenti pada umur 24 hsa (Gambar 2.).

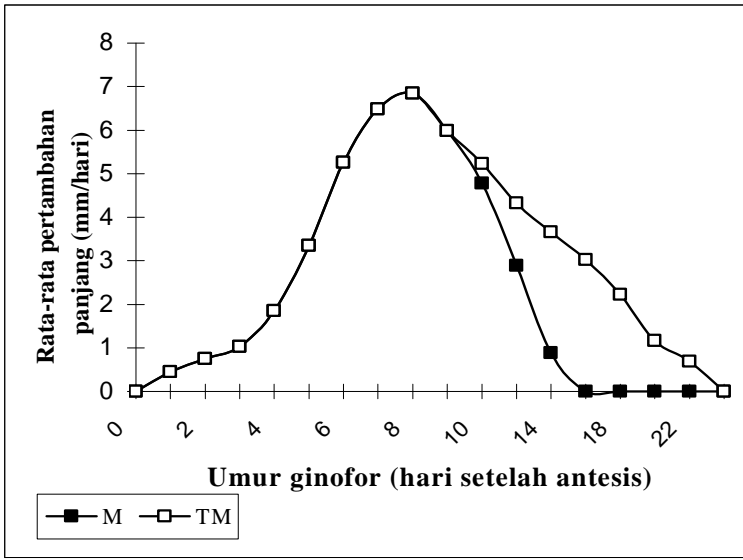

Keterangan: $\mathrm{M}=$ Masuk tanah; $\mathrm{TM}=$ Tidak masuk tanah

Gambar 2. Rata-rata pertambahan panjang setiap hari selama tahap pertumbuhan ginofor kacang tanah

Buah kacang tanah hanya dapat berkembang di dalam tanah. Pada usia panen (65 hsa), buah yang tidak masuk tanah tidak mengalami pertumbuhan dan perkembangan sama sekali, sedangkan buah yang mulai umur 8-10 hsa sudah masuk tanah, pada umur 15 hsa sudah mulai membesar dan tumbuh dengan cepat sampai umur 23 hsa (Gambar 1 dan 3).

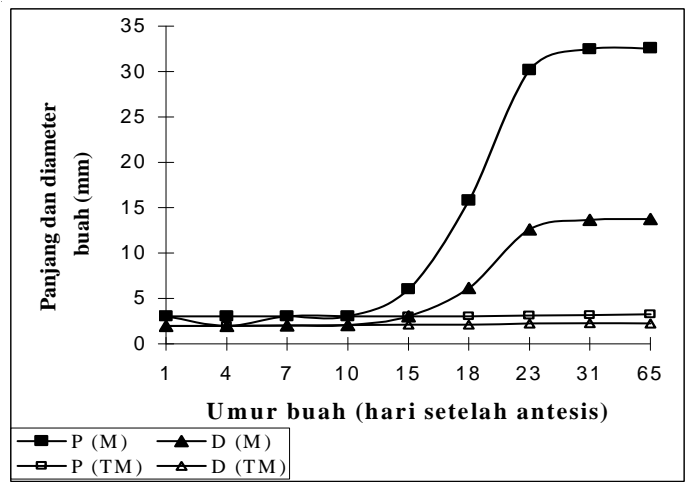

Keterangan: $\mathrm{P}=$ Panjang buah; $\mathrm{D}=$ Diameter buah; $\mathrm{M}=$ Masuk tanah; TM = Tidak masuk tanah

Gambar 3. Kurva pertumbuhan selama tahap perkembangan buah kacang tanah 
Seperti halnya perkembangan buah, biji kacang tanah juga tidak mengalami perkembangan pada buah yang tidak masuk ke dalam tanah. Pertumbuhan biji dimulai pada saat buah mulai tumbuh (umur 15 hsa), dan kecepatan pertumbuhan maksimal terjadi pada saat pertumbuhan buah sudah terhenti (umur 23-31 hsa). Setelah umur 31 hsa sampai usia panen (65 hsa) pertumbuhan biji sangat lambat (Gambar 4).

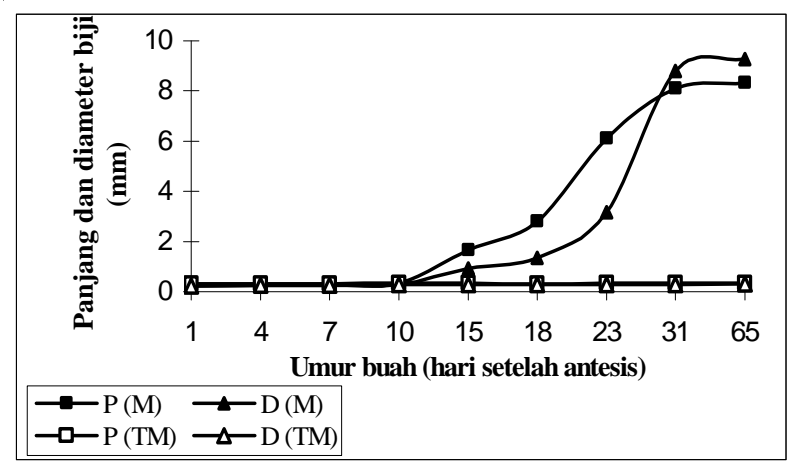

Keterangan: $\mathrm{P}=$ Panjang biji; $\mathrm{D}=$ Diameter biji; $\mathrm{M}=$ Masuk tanah; $\mathrm{TM}=$ Tidak masuk tanah

Gambar 4. Kurva pertumbuhan selama tahap perkembangan biji kacang tanah

\section{Kandungan auksin pada buah}

Gambar 5 menunjukkan salah satu contoh kurva hasil analisis kandungan auksin pada buah dengan KCKT menggunakan detektor fluorescence.

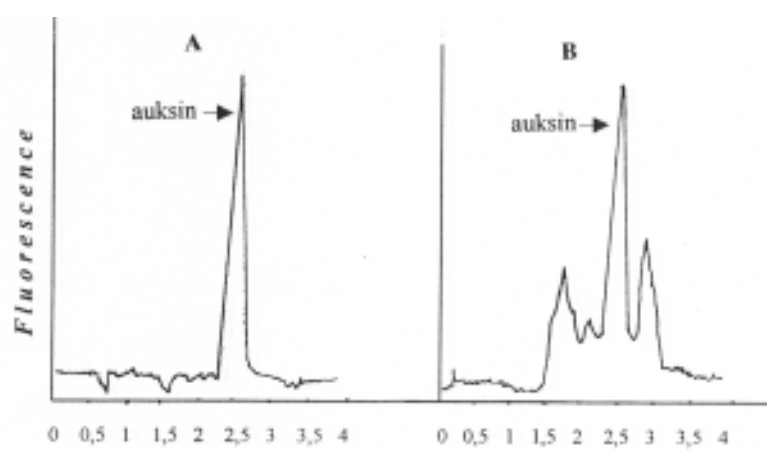

Waktu retensi (menit)

Gambar 5. Kromatografi Cair Kinerja Tinggi auksin menggunakan detektor fluorescense dengan panjang gelombang eksitasi dan emisi masing-masing 254 dan $360 \mathrm{~nm}$. (A) Auksin standar; (B) Auksin sampel

Dari hasil penghitungan pada kurva standar, diperoleh persamaan regresi hubungan antara kandungan auksin $(\mathrm{Y})$ dengan luas area (X), yaitu $Y=0,0000636885 X-0,316801$, dengan $r=0,9984$.

Hasil pengukuran kandungan auksin bebas dan terikat baik pada buah yang berkembang maupun tidak berkembang tertera pada Tabel 1 , sedangkan grafik perubahan kandungan auksin selama perkembangan buah kacang tanah tertera pada Gambar 6.

Auksin bebas dan terikat pada buah kacang tanah sudah ada sejak antesis, dan kandungannya terus meningkat sampai umur 7 hsa ( Tabel 1 dan Gambar 6). Kandungan

Tabel 1. Kandungan auksin selama perkembangan buah kacang tanah (ng/g berat basah)

\begin{tabular}{|c|c|c|c|c|c|c|c|}
\hline \multirow{3}{*}{$\begin{array}{c}\begin{array}{c}\text { Umur buah } \\
\text { (hsa) }\end{array} \\
0\end{array}$} & \multicolumn{3}{|c|}{ Buah berkembang } & \multicolumn{4}{|c|}{ Buah tidak berkembang } \\
\hline & \multicolumn{2}{|c|}{ Auksin bebas } & Auksin terikat & \multicolumn{2}{|c|}{ Auksin bebas } & \multicolumn{2}{|c|}{ Auksin terikat } \\
\hline & 3.75408 & $+0,243$ & $1.93538+0,083$ & 3.75408 & $+0,243$ & 1.93538 & $+0,083$ \\
\hline 4 & 115.11907 & $+5,446$ & $1.59157+0,104$ & 115.11907 & $+5,446$ & 1.59157 & $+0,104$ \\
\hline 7 & 144.81789 & $+4,479$ & $22.5833+0,892$ & 144.81789 & $+4,479$ & 22.5833 & $+0,892$ \\
\hline 10 & 131.6694 & $\begin{array}{l} \pm \\
+7,235\end{array}$ & $17.70872+0,753$ & 131.6694 & $\begin{array}{l} \pm \\
+7,235\end{array}$ & 17.70872 & $\begin{array}{l} \pm 0,753 \\
\pm \quad 0,75\end{array}$ \\
\hline 15 & 60.24048 & $\pm 2,903$ & $8.71975 \pm 0,425$ & 38.3122 & $\pm 2,468$ & 60.3074 & $\pm 3,243$ \\
\hline 18 & 90.82155 & $\begin{array}{l} \pm \\
+4,286\end{array}$ & $5.0987 \pm 0,426$ & 34.5603 & $\begin{array}{l} \pm 2,278 \\
\pm 2,1\end{array}$ & 52.6475 & $\begin{array}{l} \pm \\
\pm \quad 3,882\end{array}$ \\
\hline 23 & 33.75153 & $\begin{array}{l} \pm \\
+\quad 1,823\end{array}$ & $16.33613 \pm 1,122$ & 31.6602 & $\begin{array}{l} \pm \\
+\quad 2,321\end{array}$ & 49.5081 & $\begin{array}{l} \pm \\
\pm \quad 2,648\end{array}$ \\
\hline 31 & 19.34275 & $\begin{array}{l} \pm \\
\pm \quad 0,643\end{array}$ & $18.62222 \pm 0,843$ & 25.4082 & $\begin{array}{l} \pm \\
\pm \quad 1,574\end{array}$ & 41.6755 & $\pm 0,118$ \\
\hline
\end{tabular}


auksin bebas pada buah yang berkembang, mulai saat antesis sampai umur 31 hsa jauh lebih tinggi dibandingkan dengan auksin terikat. Peningkatan kandungan auksin bebas secara drastis terjadi hingga 7 hsa, kemudian menurun sampai umur 15 hsa. Pada umur 15-18 hsa kandungan auksin bebas meningkat lagi, kemudian terjadi penurunan hingga 31 hsa (Gambar 6a.).

Pada buah yang tidak berkembang, sebelum umur 15 hsa kandungan auksin bebas lebih tinggi dari pada auksin terikat, sedangkan setelah umur 15 hsa kandungan auksin terikat lebih tinggi daripada auksin bebas (Gambar 6b).
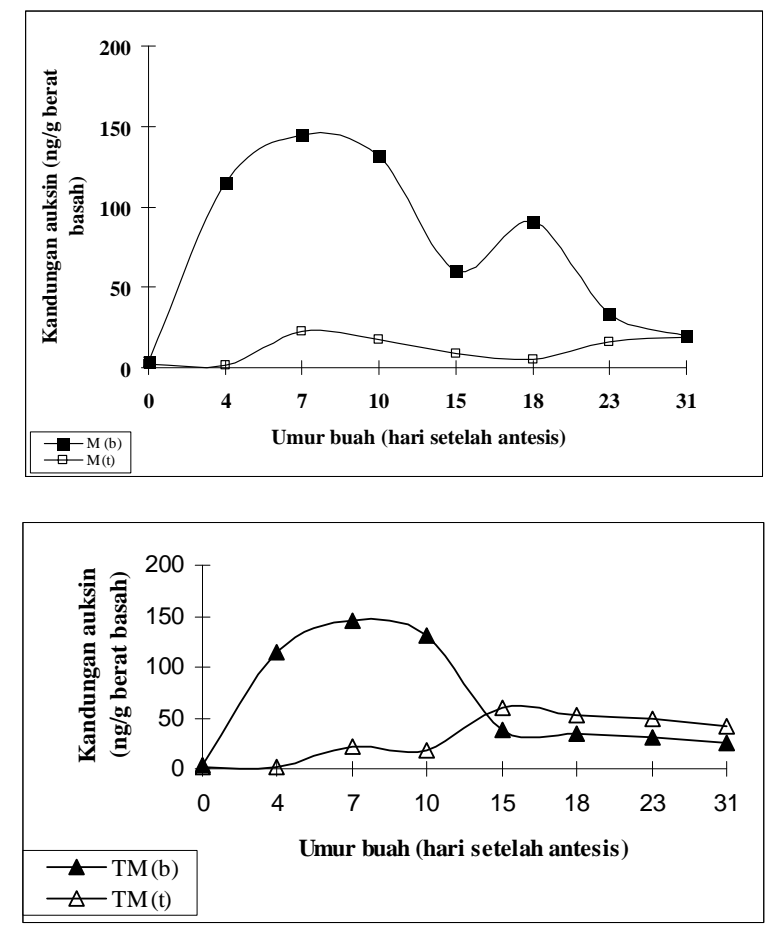

Keterangan: $\mathrm{M}=$ Masuk tanah; $\mathrm{TM}=$ Tidak masuk tanah; $\mathrm{b}=$ auksin bebas; $\mathrm{t}=$ auksin terikat

Gambar 6. Kandungan auksin selama perkembangan buah kacang tanah a) Buah masuk tanah; b) Buah tidak masuk tanah

\section{PEMBAHASAN}

Pembentukan buah dan biji pada siklus hidup tumbuhan tingkat tinggi merupakan suatu adaptasi yang unik. Perkembangan buah dan biji yang melibatkan berbagai proses fisiologi adalah salah satu cara tumbuhan agar dapat mempertahankan generasinya. Dalam perkembangan buah dan biji tersebut salah satunya dikendalikan oleh auksin (Quatrano, 1990).

Kandungan auksin yang berubah-ubah memainkan peran yang sangat penting dalam perkembangan buah kacang tanah. Hal ini disebabkan oleh kebutuhan auksin pada setiap jaringan pada berbagai tahap perkembangan tidak sama besar (Moore, 1989; Quatrano, 1990). Menurut Davies (1990) perubahan kebutuhan auksin pada setiap tahap perkembangan tumbuhan disebabkan oleh adanya perubahan jumlah, afinitas, dan bentuk reseptor pada membran sel. Pada tingkat molekuler, perubahan kebutuhan auksin tergantung pada jumlah gen responsif auksin yang aktif (Guilfoyle et al., 1998). Peran auksin pada ekspresi gen antara lain adalah sebagai penghantar sinyal (Fosket, 1994; Guilfoyle et al., 1998), membebaskan DNA dari histon (Hopkin, 1995) dan mempengaruhi faktor transkripsi beberapa gen yang mengendalikan pemanjangan dan pembelahan sel, diferensiasi, dan perkembangan embrio (Guilfoyle et al., 1998).

Tumbuhan mampu meregulasikan dengan baik agar kandungan auksin pada jaringan relatif stabil sesuai dengan yang dibutuhkan, yaitu dengan mengatur sintesis, transpor dan konjugasi (Moore, 1989; Davies, 1990;). Kelebihan auksin pada suatu jaringan akan dikurangi dengan cara mengubah menjadi konjugat, mentranspor ke jaringan lain atau dengan menghentikan sintesis, sedangkan apabila terjadi kekurangan akan disuplai dengan menghidrolisis konjugat, mentranspor dari jaringan lain atau meningkatkan sintesis (Moore, 1989; Reinecke \& Bandurski, 1990).

Pada saat antesis (sebelum fertilisasi), bakal buah kacang tanah sudah mengandung auksin, baik bebas maupun terikat. Penelitian Moctezuma (1999) menggunakan antibodi monoklonal menunjukkan bahwa, sebelum fertilisasi tidak ada sintesis auksin pada bakal buah kacang tanah. Menurut ShuPing et al., (1996), fertilisasi pada kacang tanah terjadi pada 21 jam setelah antesis. Dengan demikian adanya auksin bebas pada bakal buah tersebut dapat dipastikan berasal dari jaringan lain yang ditranspor ke bakal buah atau hasil penguraian auksin terikat. Auksin dalam bakal buah tersebut antara lain digunakan untuk mengontrol pembelahan (Guilfoyle et al., 1998) dan polarisai sel (Fowler, 2002). Menurut Howel (2000), sporogenesis dan gametogenesis di dalam bakal buah salah satunya juga dikontrol auksin.

Kandungan auksin yang tinggi pada awal perkembangan buah kacang tanah (4-10 hsa), merupakan bentuk regulasi tumbuhan untuk mengatur kesesuaian jumlah auksin dengan kebutuhan jaringan. Kandungan auksin yang tinggi pada buah tersebut antara lain digunakan untuk pertumbuhan endosperm dan perkembangan embrio (Smith, 1956; Quatrano, 1990; Rock \& Quatrano, 1995) serta pertumbuhan dan orientasi ginofor (Smith, 1956; Moctezuma \& Feldman, 1998). Menurut Smith (1956), inti endosperm kacang tanah membelah dengan cepat pada awal perkembangan dan kecepatannya menurun seiring dengan 
bertambahnya stadium perkembangan buah. Embrio kacang tanah pada umur 7 hsa berada pada stadium pro embrio antara 6-8 sel (Patte \& Mohapatra, 1987; Sulistiono, 2000). Pada stadium tersebut dan stadium sebelumnya embrio memerlukan auksin yang lebih banyak daripada stadium selanjutnya. Pada embrio somatik kacang tanah (Wetztein \& Baker, 1993), tambahan auksin eksogen hanya diperlukan pada awal pembentukan embrio, sedangkan untuk perkembangan selanjutnya auksin eksogen tidak diperlukan.

Auksin yang dihasilkan buah kacang tanah sebagian ditranspor secara basipetal dan digunakan untuk pertumbuhan ginofor (Smith, 1956; Moctezuma \& Feldman, 1998). Pertumbuhan ginofor yang meningkat dengan cepat pada umur 4-10 hsa, menunjukkan terjadinya pembelahan dan pemanjangan sel yang cepat pula pada meristem interkalar ginofor (Moctezuma, 1998). Sel-sel yang aktif membelah dan memanjang memerlukan auksin lebih banyak daripada sel yang tidak aktif (Moore, 1989; Cleland, 1990; Fosket, 1994).

Berkurangnya kandungan auksin bebas pada buah yang masuk tanah pada umur 10 sampai 15 hsa karena sebagian besar ditranspor ke ginofor (Smith, 1956) dan diubah menjadi auksin terikat. Hal ini terbukti dengan meningkatnya kandungan auksin terikat. Pertumbuhan ginofor yang semakin lambat setelah umur 8 hsa, kemungkinan disebabkan oleh terlalu tingginya kandungan auksin. Menurut Smith (1956), kandungan auksin yang terlalu tinggi pada ginofor akan menghambat pertumbuhan ginofor tersebut. Pemberian inhibitor transpor auksin yang dapat menghambat transpor auksin dari buah ke ginofor menggunakan morfaktin (Mnzava \& Flocker, 1978) dan 2,3,5-Triiodobenzoic acid (TIBA) (Sulistiono, 2000) dapat mempercepat pertumbuhan ginofor tersebut.

Buah kacang tanah yang masuk ke dalam tanah, pada umur 15 hsa mulai membesar dan mencapai ukuran maksimal pada umur 23 hsa. Pada fase pertumbuhan tersebut sel-sel pada kulit buah mengalami pembelahan dan pembesaran dengan cepat (Gillaspy, et al., 1993 dalam Howell, 2000), sehingga memerlukan auksin dalam jumlah yang lebih banyak (Cleland, 1990; Quatrano, 1990). Kandungan auksin yang tinggi pada buah umur 15-18 hsa juga digunakan untuk embrio yang tumbuh dan berkembang dengan cepat, yaitu dari stadium globular awal pada umur 15 hsa, menjadi stadium kotiledon pada umur 18 hsa (Sulistiono, 2000). Selain itu kandungan auksin yang tinggi juga digunakan untuk memacu sintesis etilen yang akan digunakan oleh buah pada fase perkembangan selanjutnya (Ludford, 1990). Menurut Schenk (1961 dalam
Ziv \& Zamaki, 1975), produksi auksin pada buah kacang tanah yang sudah masuk tanah menurun drastis, sehingga untuk memenuhi kebutuhan auksin yang tinggi pada buah umur 15-18 hsa tersebut dilakukan pembongkaran auksin terikat menjadi auksin bebas (terbukti dengan menurunnya kandungan auksin terikat seperti pada Gambar 6a.).

Sel-sel pada jaringan buah yang telah memasuki fase penuaan tidak mengalami pembelahan dan pemanjangan sebagai akibat rendahnya kandungan auksin dan meningkatnya asam absisat serta etilen (Quatrano, 1990; Ludford, 1990; Ludford, 1995; Howell, 2000). Menurunnya kandungan auksin bebas tersebut karena adanya pengubahan menjadi auksin terikat dan disimpan di dalam biji sebagai cadangan. Auksin terikat pada biji tersebut akan dihidrolisis menjadi auksin bebas pada saat biji berkecambah (Moore, 1989).

Kebutuhan auksin pada jaringan yang tidak aktif membelah lebih sedikit dibandingkan dengan jaringan yang aktif membelah (Davies, 1990). Pada buah kacang tanah yang tidak berkembang pembelahan sel terjadi sangat lambat atau mungkin tidak terjadi sama sekali, sehingga hampir tidak terjadi penambahan ukuran buah sampai usia panen. Rendahnya kandungan auksin bebas pada buah yang tidak berkembang juga disebabkan oleh tidak berkembangnya embrio, yaitu mulai umur 6 hsa sampai usia panen tertahan pada stadium pro embrio antara 6-8 sel (Patte \& Mohapatra, 1987; Sulistiono, 2000). Meningkatnya kandungan auksin terikat pada buah mulai umur 10 hsa, menunjukkan telah terjadi pengubahan auksin bebas menjadi auksin terikat, karena auksin bebas yang ada tidak dipergunakan.

Dari hasil penelitian ini dapat disimpulkan sebagai berikut:

1. Kandungan auksin pada buah kacang tanah berubahubah sesuai dengan kebutuhan buah pada setiap tahap perkembangannya.

2. Kandungan auksin bebas pada buah yang berkembang lebih tinggi daripada buah yang tidak berkembang, sedangkan kandungan auksin terikat pada buah yang berkembang lebih sedikit dari pada buah yang tidak berkembang.

\section{KEPUSTAKAAN}

Amir J, 1969. A Study on the Reproductive Stage of the Groundnut, Arachis hypogaea L. Ann. Bot. 33: 333-338.

Cleland RE, 1990. Auxin and Cell Elongation. In: Davies PJ. (Edit.) Plant Hormones and Their Role in Plant Growth and Development. Kluwer Ac. Press Pub. Boston-London. p. 132-148. 
Crozier A, Loferski K, Zaerr JB, and Morris RO, 1980. Analysis of Picogram Quantities of Indole-3-acetic Acid by High Performance Liquid Chromatography-Fluorescence Procedures. Planta. 150: 366-370.

Cutter EG, 1971. Plant Anatomy: Experiment and Interpretation. Addison-Wesley Pub. Company, California-LondonOntario. p. 246-271.

Davies PJ, 1990. The Plant Hormone Concept: Transport, Concentration, and Sensitivity. In: Davies PJ (Edit.) Plant Hormones and Their Role in Plant Growth and Development.. Kluwer Ac. Press Pub, Boston-London. p. $12-22$.

Durley RC, Kannangara T, and Simpson GM, 1982. Leaf Analysis for Abscisic, Phaseic and 3-Indolylacetic Acid by HighPerformance Liquid Chromatography. J. Chro-matogr. 236: 181-188.

Fosket DE, 1994. Plant Growth and Development. A Molecular Approach. Academic Press. New York-London-Sydney. p. 396-440.

Fowler JF, 2002. Cell Polarity in Algae and Vascular Plants. In: Dubin DG (Edit.) Cell Polarity. Oxford University Press. p. 141-180.

Guilfoyle T, Hagen G, Ulmazov T, and Murfett J, 1998. How does Auxin Turn on Gene? Plant. Physiol. 118: 341-347.

Hall MA, 1984. Hormones and Plant Development. Cellular and Molecular Aspect. In: Graham CF and Wareing PF (Edit.) Developmental Control in Animals and Plants. Blackwell Scientific. Publication. p. 313-330.

Hopkins WG, 1995. Introduction to Plant Physiology. John Wiley \& Sons, Inc., New York, Toronto, Singapore. p. 285-321.

Howell SH, 2000. Molecular Genetics of Plant Development. Cambridge University Press. p. 263-285.

Jakobs WP, 1951. Auxin Relationships in an Intercalary Meristem: Further Studies on the Gynophore of Arachis hypogaea L. Am. J. Bot. 38: 307-310.

Ludford PM, 1990. Postharvest Hormone Changes in Vegetables and Fruits. In: Plant Hormones and Their Role in Plant Growth and Development. Eds. Davies PJ. Kluwer Ac. Press Pub., Boston-London. p. 574-592.

1995. Postharvest Hormone Changes in Vegetables and Fruits. In: Plant Hormones Physiology, Biochemistry and Molecular Biology. Eds. Davies PJ. Kluwer Ac. Press Pub., BostonLondon. p. 725-750.

Maesen LJSV and Somaatmaja S, 1993. Sumber Daya Nabati Asia Tenggara I: Kacang-kacangan (terjemahan). PT. Gramedia, Jakarta. p. 25-42.

Moctezuma E and Feldman LJ, 1998. Growth Rates and Auxin Effect in Graviresponding Gynophores of Peanut, Arachis hypogaea (Fabaceae). Am. J. Bot. 43: 1369-1376.
Moctezuma E, 1999. Changes in Auxin Pattern in Developing Gynophores of the Peanut Plant (Arachis hypogaea L.) Ann. Bot. 83: 235-242.

Mnzava NA and Flocker WJ, 1978. Effect of Morphactin on Growth and Geotropism of Peanut Gynophore Explants. J. Am. Soc. Hort. Sci. 103: 574-575.

Moore TC, 1989. Biochemistry and Physiology of Plant Hormones. Edward Brothers. Inc., New York. p. 28-45.

Patte HE and Mohapatra SC, 1987. Anatomical change during Ontogeny of the Peanut (Arachis hypogaea L. Merr) Fruit: Mature Megagametophyte through Heart-Shaped Embryo. Bot. Gaz.148: 156-164.

Quatrano RS, 1990. The Role of Hormones during Seed Development. In: Plant Hormones and Their Role in Plant Growth and Development. Eds. Davies PJ. Kluwer Ac. Press Pub., Boston-London. p. 494-514

Reed RC, Brady SR, and Muday GK, 1998. Inhibition of Auxin Movement from the Shoot to the Root Inhibits Lateral Root Development in Arabidobsis. Plant. Physiol. 118: 1369-1376.

Reinecke DM and Bandurski RS, 1990. Auxin biosynthesis and metabolism. In: Plant Hormones and Their Role in Plant Growth and Development. Eds. Davies PJ. Kluwer Ac. Press Pub., Boston-London.p. 24-42.

Rock CD and Quatrano RS, 1995. The Role of Hormones During Seed Development. In: Plant Hormones Physiology, Biochemistry and Molecular Biology. Eds. Davies PJ. Kluwer Ac. Press Pub., Boston-London. p. 671-697.

ShuPing X, Xiang Yuang X, Xing, and Xi X, 1996. An Ultrastructural Study of Embryo Sac in Arachis hypogaea before and after Fertilization. Acta-Bot. Yunanica. 18: 87-92.

Smith BW, 1956. Arachis hypogaea, Embryogeny and the Effect of Pod Elongation upon Embryo and Endosperm Growth. Am. J. Bot. 43: 233-240.

Sulistiono, 2000. Pengaruh 2,3,5-Triiodobenzoic Acid terhadap Pertumbuhan Ginofor dan Perkembangan Buah Kacang Tanah (Arachis hypogaea L. Merr) varitas Rusa. (Tesis Pascasarjana). Bandung: ITB. p. 30-45.

Wetztein HY and Baker CM, 1993. The Relationship between Somatic Embryo Mor-phology and Convertion in Peanut (Arachis hypogaea). Plant Scienc 92: 81-89.

Ziv M and Zamski E, 1975. Geotropic Responses and Pod Development in Gynophore Explants of Peanut (Arachis hypogaea) Cultured In Vitro. Ann. Bot. 39: 579-583.

Reviewer: Prof. Dr. Santoso 